\title{
MRI Visualization of CSF Flow
}

\author{
Edward Frederick Melamed ${ }^{1 *}$, Skorn Ponrartana ${ }^{2}$, Eisha Anne Christian ${ }^{3}$, Matthew Borzage ${ }^{2}$, Stefan Bluml2, \\ J Gordon McComb ${ }^{1}$
}

From Hydrocephalus 2015

Banff, Canada. 18-21 September 2015

\section{Introduction}

The ability to non-invasively establish patency of cerebral spinal fluid (CSF) flow between adjacent central nervous system (CNS) compartments is of importance in the diagnosis and treatment of patients with various areas of CSF flow obstruction. Recent advances in magnetic resonance imaging (MRI) technology allows for real-time magnetic labeling of CSF to directly visualize flow through different compartments.

\section{Methods}

The presence of CSF flow was examined at the aqueduct of Sylvius (AS), the foramen of Monro (FM), the floor of the third ventricle (3rd V), and the foramen magnum (FMag) using a modification of arterial spin labeling (ASL). The studies were compared with clinical information and classified as true positive, true negative, false positive, and false negative based on expectation of patency.

\section{Results}

A total of 68 flow studies were done on 44 patients. High correlation with true positive was seen at all four sites. No flow was visualized in 25 readings of the AS; in 9 of those cases we expected flow to be present. Table 1.

\section{Conclusion}

Establishing qualitative patency between adjacent CSF compartments using MRI is possible with a modified ASL technique. This technique has excellent (above 80\%) sensitivity, specificity, and negative likelihood ratio in three out of the four regions studied.

\footnotetext{
Authors' details

${ }^{1}$ Division of Neurosurgery, Children's Hospital Los Angeles, CA, USA.

2Department of Radiology, Children's Hospital Los Angeles, CA, USA.
}

\footnotetext{
* Correspondence: emelamed@chla.usc.edu

'Division of Neurosurgery, Children's Hospital Los Angeles, CA, USA

Full list of author information is available at the end of the article
}

Table 1

\begin{tabular}{lllll}
\hline AS & FM & 3rd & V & FMag \\
\hline Positive-True & $26 / 26$ & $8 / 8$ & $12 / 12$ & $30 / 30$ \\
\hline False & $0 / 26$ & $0 / 8$ & $0 / 12$ & $0 / 30$ \\
\hline Negative-True & $16 / 25$ & $0 / 2$ & $2 / 3$ & $1 / 3$ \\
\hline False & $9 / 25$ & $2 / 2$ & $1 / 3$ & $2 / 3$ \\
\hline Specificity & $100 \%$ & $0 \%$ & $100 \%$ & $100 \%$ \\
\hline Sensitivity & $74 \%$ & $80 \%$ & $92 \%$ & $94 \%$ \\
\hline Negative & LR 0.26 & Undefined & 0.08 & 0.06 \\
\hline
\end{tabular}

${ }^{3}$ Department of Neurological Surgery, Keck School of Medicine, University of Southern California, Los Angeles, CA, USA.

Published: 18 September 2015

\section{Reference}

1. Christian EA, Melamed EF, Peck E, Krieger MD, McComb JG: Surgical Management of Hydrocephalus Secondary to Intraventricular Hemorrhage in the Preterm Infant. I Neurosurg Pediatrics, [Accepted for Publication June 18, 2015].

doi:10.1186/2045-8118-12-S1-P33

Cite this article as: Melamed et al:: MRI Visualization of CSF Flow. Fluids and Barriers of the CNS 2015 12(Suppl 1):P33.

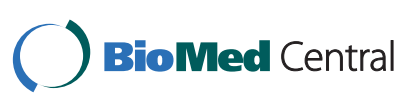

Submit your next manuscript to BioMed Central and take full advantage of:

- Convenient online submission

- Thorough peer review

- No space constraints or color figure charges

- Immediate publication on acceptance

- Inclusion in PubMed, CAS, Scopus and Google Scholar

- Research which is freely available for redistribution Submit your manuscript at
www.biomedcentral.com/submit C Biomed Central 